\title{
The biomass-density relationship in seagrasses and its use as an ecological indicator
}

\author{
Vasco M. N. C. S. Vieira ${ }^{1 *}$ (D) Inês E. Lopes ${ }^{1}$ and Joel C. Creed ${ }^{2}$
}

\begin{abstract}
Background: Biomass-density relations have been at the centre of a search for an index which describes the health of seagrass meadows. However, this search has been complicated by the intricacy of seagrass demographics and their complex biomass-density relations, a consequence mainly of their modular growth and clonality. Concomitantly, biomass-density upper boundaries have been determined for terrestrial plants and algae, reflecting their asymptotic maximum efficiencies of space occupation. Each stand's distance to its respective biomass-density upper boundary reflects its effective efficiency in packing biomass, which has proved a reliable ecological indicator in order to discriminate between taxonomic groups, functional groups and clonal vs. non-clonal growth.

Results: We gathered data from 32 studies on 10 seagrass species distributed worldwide and demonstrated that seagrasses are limited by their own boundary line, placed below the boundaries previously determined for algae and terrestrial plants. Then, we applied a new metric - $d_{\text {grass }}$ : each stand's perpendicular distance to the seagrass boundary-and used this parameter to review fundamental aspects such as clonal growth patterns, depth distribution, seasonality, interspecific competition, and the effects of light, temperature and nutrients.
\end{abstract}

Conclusions: Seagrasses occupy space less efficiently than algae and terrestrial plants. Using only their biomass and density data we established a new and efficient tool to describe space occupation by seagrasses. This was used with success to evaluate their meadows as an ecological indicator for the health of coastal ecosystems.

Keywords: Ecosystem, Seagrass, Coastal, Index, Meadow, Nutrient, Pollution

\section{Background}

When individuals in an even-aged monospecific plant stand undergo active growth increasing their biomass, competitive stress may induce mortality. The consequent elimination of the weaker plants releases resources (space, light and nutrients) facilitating the further growth of survivors. This dynamic, commonly known as self-thinning, also reflects the efficiency of space occupation as more efficient stands (or species) exhibit higher biomasses under similar stand densities (numbers of individuals per unit area). The first studies of self-thinning, dating from the 1950s onwards

\footnotetext{
*Correspondence: vasco.vieira@tecnico.ulisboa.pt

${ }^{1}$ MARETEC, Instituto Superior Técnico, Universidade Técnica de Lisboa, Av. Rovisco Pais, 1049-001 Lisbon, Portugal

Full list of author information is available at the end of the article
}

[1-4], established a relationship between density (D) and mean plant mass $(\mathrm{w})$ given by $w=k D^{-3 / 2}$ or equivalently $\log _{10} w=\log _{10} k-1.5 \log _{10} D$. Here, $w$ refers to above-ground biomass and $k$ is an allometric constant. In addition to many reported self-thinning slopes in plants ranging from small herbs to trees being close to $-3 / 2$, the law has also been applied to some mixed species stands [5] and across species regressions of different sized plants [6, 7]. Later the relationship evolved into an equivalent derived from stand biomass per unit area $(B)$ and density: $B=k D^{-1 / 2}$ or equivalently $\log _{10} B=\log _{10} k-0.5 \log _{10} D$ [8]. This new relation solved two problems: (i) auto-correlation, as the former $w-D$ relation required the number of individuals to estimate the quantities on both sides of the equation, and (ii) mean biomass increasing without actual growth 
but just because smaller individuals died [8,9]. This was the first improvement aiming at establishing a set of best-practices for the assessment of biomass-density relations and involving aspects such as the data quality and choice of regression methods $[9,10]$. More recently, the numerical aspects were further improved with the development and application of model 2 quantile regression and careful data screening [11, 12]. These adjustments brought about the realization that the slope of the biomass-density regression should be reset at values closer to $-0.33[10,13]$. Despite these advances, substantial debate followed as to what the self-thinning "law" is as well as controversy as to whether a law really existed at all $[10,14,15]$. Henceforth, biomass-density relationships were categorized into three different aspects (Fig. 1):

a. The (intraspecific) dynamic self-thinning line is the straight line that is approached, then followed by the time trajectory of a crowded monospecific stand as it grows [9, 10, 13-15]. Stands may have different dynamic thinning lines depending on the environmental conditions (= carrying capacity). Changes in the slope and intercept of this dynamic thinning line for stands of the same species usually relate to the allometry of a plant species [16] as well as to resource or temperature limitation [17-19]. In the later cases, flatter slopes associated with lower intercepts reflected smaller carrying capacities of the environment.

b. The species (or higher ranked taxon) boundary linethe upper boundary of possible biomass-density combinations for a given taxon from the plant kingdom [15]. This line is fit to the most extreme densitybiomass combinations of hundreds of stands of the same taxon. Theoretically, the y-intercept of a taxon provides information about its maximum capacity to pack biomass above-ground.

c. The interspecific biomass-density relationship (IBDR [20]) and its static upper boundary characterizing the maximum biomass-density limit for all the species which make up the plant kingdom. Weller [13] analysed plant data setting the boundary at $\log _{10} \mathrm{~B}=3.91-0.33 \log { }_{10} \mathrm{D}$. However, this boundary was estimated from Ordinary Least Squares (OLS) and thus, although applied to the most extreme stands, it still determined a central tendency. Consequently, Scrosati [20] re-analysed the data from Weller [13] setting the plant boundary at $\log _{10} \mathrm{~B}=4.87-0.33 \log _{10} \mathrm{D}$ and dubbing it ultimate biomass-density Line (UBDL) [21]. More recently, Creed et al. [12] termed this boundary the interspecific boundary line (IBL).

Since the 1980s phycologists have tested the biomassdensity relations in seaweeds, generally obtaining results
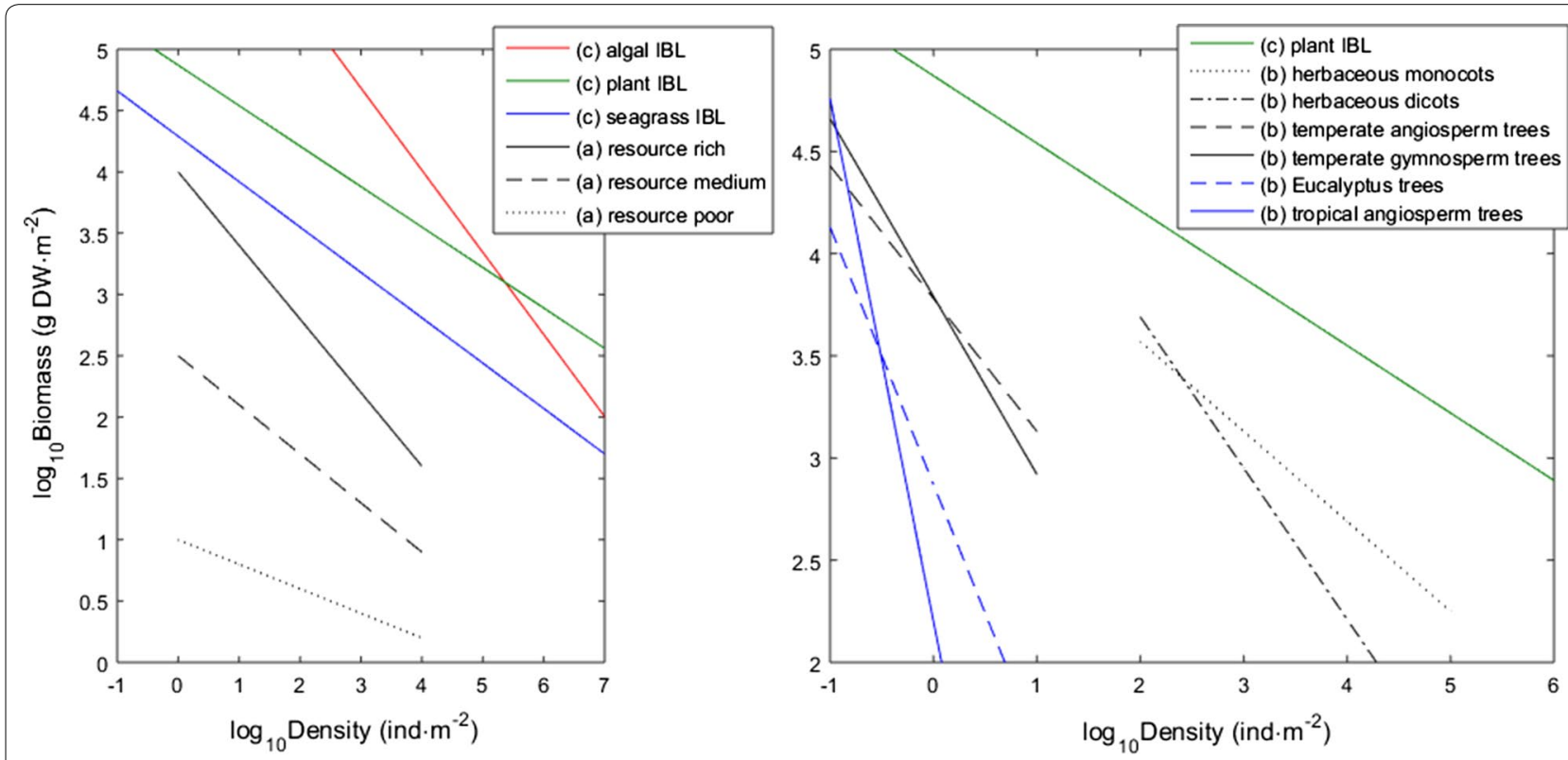

Fig. 1 Biomass-density relationships. The trajectories in (a) are a schematic of the generalized observed pattern with the stands'specific relationships dependent from resource availability. These were not drawn from observed data nor represent any specific taxon. The trajectories in (b) are taxon specific Boundary Lines drawn from data of Weller [9]. The trajectories in (c) are the interspecific boundary lines (IBL) of plants [20], algae [12] and seagrass (estimated in this study) 
similar to those obtained from land plants [22-27]. However, a recent analysis of data revealed that algae occupy space more efficiently [12]. With a higher intercept and steeper slope $\left(\log _{10} \mathrm{~B}=6.69-0.67 \log _{10} \mathrm{D}\right)$, the algal IBL was placed significantly higher than the plant IBL (Fig. 1), thus representing the ultimate boundary known for any life-type on the planet. The higher efficiency of algae was considered to be a consequence of the aquatic environment which facilitates the algal morphology and ecophysiology relative to that of plants. Compared to land plants, algae are neither limited by water availability nor bare costs of transporting water for transpiration; they also acquire nutrients and photosynthesize through the whole of their surfaces, and do not require (non-photosynthetic) deep roots or rigid tissues for support as buoyancy keeps them upright.

Seagrasses grow by the iteration of modules which may remain physiologically integrated or separate to form clones. Previously it has been shown in plants and algae that the intraspecific dynamic biomass-density relationship (self-thinning) often does not apply to clonal species. These may have clonal integration because modules (ramets) belong to the same genetic individual (genet) and are physically interconnected, which may allow the sharing of acquired resources between ramets and offset competition [28]. Consequently, an increase of stand biomass may arise from the increase in plant (ramet) sizes, increase in plant (ramet) density, or both. Hutchings [28] identified several non-thinning biomass-density dynamics typical of clonal plants. On the other hand, Westoby [29] and de Kroon and Kalliola [30] identified clonal plants where the specificities of their life-histories may (or not) lead them to self-thin, depending on additional factors. The occurrence of self-thinning is also variable in clonal algae and seems to depend on their specific life-history, morphological characteristics and habitat [20,31-34]. Although not necessarily self-thinning, terrestrial clonal plants and clonal algae were nevertheless demonstrated to be limited by an IBL $[12,28]$. Thus, it was still possible to use their stand's distance to their IBL as an estimator of their efficiency of space occupation. Having proved applicable to all sorts of algae, both clonal and non-clonal, this new method provided exciting new evidence about algal growth and ecology [12]. In this work we tested whether the same applies to seagrasses. Taxonomically, seagrasses are flowering plants (i.e., angiosperms), sharing with their terrestrial counterparts the features that make angiosperms the most complex taxa among autotrophic life-forms: as well as having flowers they also possess rigid tissues, extensive roots and a primary circulatory system carrying water and nutrients. On the other hand, they spend a significant part (if not all) of their life underwater, where they can also benefit from the water environment, as do macroalgae. Furthermore, in contrast to terrestrial angiosperms, seagrasses acquire nutrients both through their leaves and roots, a capacity that can even become essential for their metabolic rates [35]. Given this seagrass duality, the first question arising is whether seagrasses pack above-ground biomass similarly to algae and/or terrestrial plants?

The dynamic self-thinning line is thought to depend intrinsically on the plant taxon being considered, besides being dependent extrinsically on the environmental carrying-capacity (proposed by Weller $[9,13,16]$ ). Biologically more complex plants, appearing later in Life's evolutionary history and generally comprehending larger individuals (namely trees), showed significantly steeper slopes along with lower intercepts (Fig. 1). Backed by elementary biostatistics, ecological theory proposed the intercept as a standard to estimate the biomass carrying capacity under equivalent densities. Hence, Weller's results suggested that simpler plants occupy space (i.e., pack above-ground biomass) more efficiently. Weller's [9] finding was refuted by Lonsdale [10] on alleged methodological grounds. Recently, new evidence emerged corroborating Weller's findings. Creed et al. [12] also found that the algal efficiency of space occupation varies with algal traits, namely with taxonomic group, functional group and clonality. And similarly to Weller's analysis simpler taxa occupy space more efficiently. Concurrently, the ability of plant communities to pack biomass into the volume effectively exploited has been demonstrated to depend on biodiversity and on the efficiency of resource exploitation [36]. Creed et al. [12] obtained their results using a more straightforward and robust methodology than the one used by Weller [9] with each stand being measured by its perpendicular distance to the algal IBL $\left(d_{\text {algal }}\right)$. Following the results obtained by Weller [9], Proulx et al. [36] and Creed et al. [12], in this study we use the perpendicular distance to the seagrass IBL $\left(\mathrm{d}_{\text {grass }}\right)$ to test whether different species show different efficiencies of space occupation in seagrasses too.

As seagrasses occur at the interface of land and sea they suffer diverse stressors, one of which is eutrophication [37]. Increasing nutrient loadings are potentially toxic and also promote blooms of opportunistic macrophytes [38]. Both effects have a negative impact on biomass or density in seagrass stands that may extend to the whole ecosystem [37-42]. Seagrasses more impacted by algal competitors tended to be smaller and/or less abundant (see Fig. 2 in Thomsen et al. [40]). As seagrasses are foundation species the dynamics of their stands has been used as a proxy for ecosystem health [39, 43-47]. The recent methodology by Creed et al. [12], which congregates the biomass and density data into a single metric irrespective of their specific correlation, estimates the stands' 


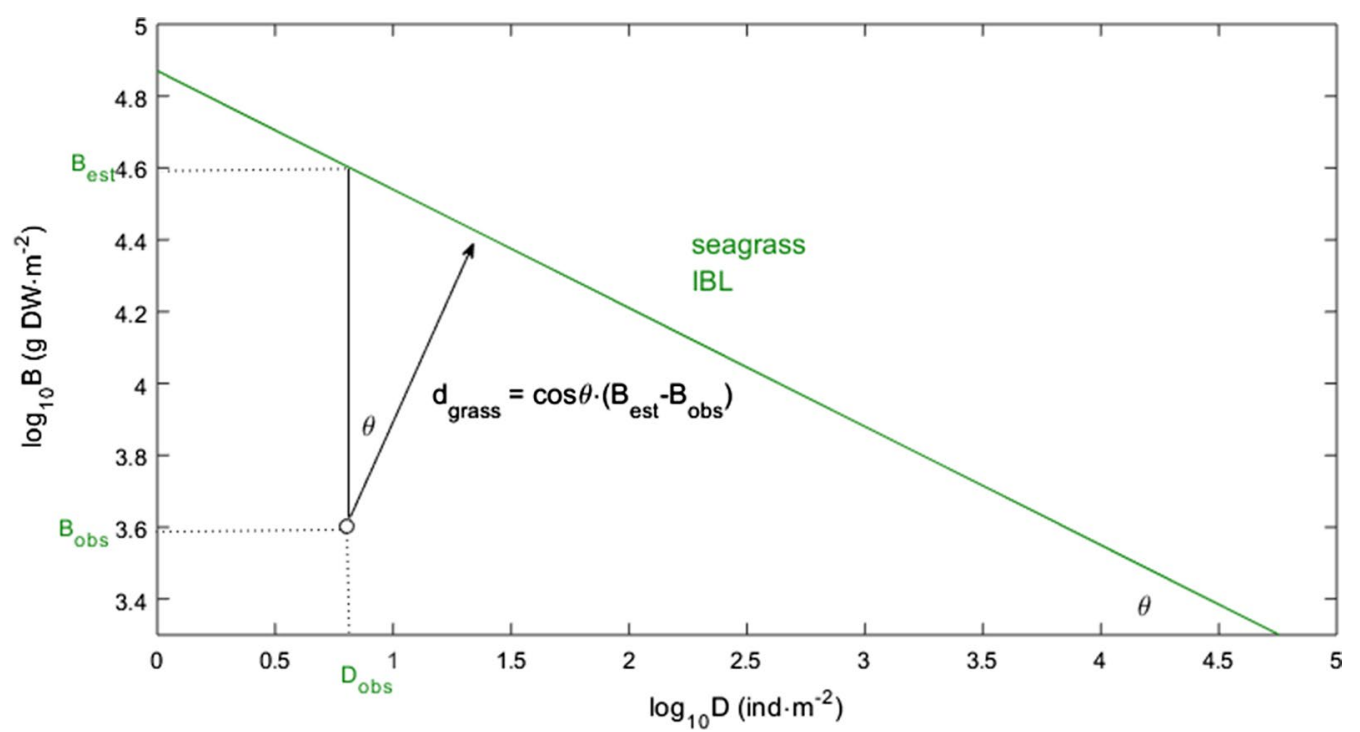

Fig. 2 Estimation of the perpendicular distances $\left(d_{\text {grass }}\right.$ ). These are estimated from the observed (obs) and estimated (est) biomass (B) and density (D), and the seagrass IBL

efficiency of space occupation. We test here whether this metric applied to seagrasses is a meaningful ecological indicator. Do healthier seagrass stands better optimize their above-ground space occupation by falling closer to a biomass-density boundary line?

\section{Methods}

\section{Biomass-density data retrieval}

We gathered data of shoot density and above-ground biomass from 32 studies on 10 seagrass species distributed worldwide (Table 1). Most of the Halodule wrightii data was provided by one author (J.C.C.). The data from Plus et al. [48] was provided by Dr Martin Plus. The remaining data was retrieved from the respective publications using appropriate software. The compilation of data was carried out during years 2017 and 2018, and used the Google search engine as well as the search engines in the webpages of all cited publications. The search keywords included 'biomass,' 'density', 'seagrass' and the species scientific denominations. We also searched the publication listings of the most cited authors in the subject and the reference lists of the cited works.

\section{Biomass-density data analysis}

From the 2954 biomass-shoot density observations available we selected the 500 closer to the top right corner of the seagrass biomass-density plot. With these 500 observations we estimated a seagrass-specific IBL following the procedure described by Creed et al. [12] and choosing the $99.9 \%$ quantile for the linefit. Once this boundary was known, we estimated the stands' perpendicular distances to this line (the $d_{\text {grass }}$ presented in "The $d_{\text {grass }}$ metric" section below) in order to test:

i. How seagrasses worldwide have different efficiencies of space occupation. However, the data comprised species with widely different numbers of observations, which would inevitably bias comparisons based on properties of the samples' distributions. In an attempt to overcome this problem and simultaneously compare among seagrasses at their maximum efficiency, for this task we selected from each taxon the five observations with the smallest $\mathrm{d}_{\text {grass; }}$

ii. How Z. marina and Z. japonica in Dadae Bay show different efficiencies of space occupation while inhabiting the same shoreline;

iii. How the efficiency of space occupation varies seasonally and spatially;

iv. How the efficiency of space occupation varies with light, temperature and nutrient concentrations.

\section{The $d_{\text {grass }}$ metric}

The estimation of each stand's perpendicular distance to the seagrass IBL $\left(\mathrm{d}_{\text {grass }}\right)$ requires the linear coefficients of this boundary line. With the general IBL equation corresponding to $\log _{10} B=\beta_{0}+\beta_{1} \log _{10} \mathrm{D}$, the coefficients for the seagrass IBL were $\beta_{0}=4.569$ and $\beta_{1}=-0.438$ (as presented in "Results" and "Discussion" sections). The angle $\theta$ between the $d_{\text {grass }}$ vector (oblique in the $\log _{10} \mathrm{~B}$-to- $\log _{10} \mathrm{D}$ orthogonal plane) and 
Table 1 Meta-data used for the seagrass biomass-density relation

\begin{tabular}{|c|c|c|c|c|}
\hline Species & Sources & No. obs. & Location & Latitude \\
\hline Cymodocea nodosa & Agostini et al. [72] & 12 & Urbinu lagoon, Corsica & 42.02 \\
\hline Cymodocea nodosa & Duarte and Sand-Jensen [71] & 47 & Ebro Delta, Spain & 40.72 \\
\hline Cymodocea nodosa & Sghaier et al. [75] & 36 & Monastir Bay, Tunisia & 35.37 \\
\hline Cymodocea nodosa & Peduzzi and Vukovic [74] & 17 & Golf of Trieste, Italy & 45.7 \\
\hline Cymodocea nodosa & Cunha e Duarte [73] & 5 & Ria Formosa, Portugal & 37.10 \\
\hline Halodule wrightii & Hall et al. [60] & 12 & Florida Bay, USA & 25.14 \\
\hline Halodule wrightii & Creed (this study) & 992 & Multiple sites, American continent & - \\
\hline Posidonia oceanica & Terrados and Pons [76] & 5 & Magaluf, Mallorca Island, Spain & 39.30 \\
\hline Posidonia oceanica & Terrados and Pons [76] & 5 & Ses Salines, Mallorca Island, Spain & 39.15 \\
\hline Posidonia sinuosa & Keulen [77] & 14 & Shoalwater bay, Queensland, Australia & -22.42 \\
\hline Posidonia sinuosa & Collier et al. [78] & 18 & Cockburn \& Warnbro sounds, Western Australia & -32.17 \\
\hline Posidonia sinuosa & Fraser and Kendrick [79] & 45 & Cockburn \& Warnbro sounds, Western Australia & -32.17 \\
\hline Syringodium filiforme & Hall et al. [60] & 2 & Florida Bay, USA & 25.14 \\
\hline Thalassia hemprichii & Larsson [70] & 3 & Inhaca \& Portuguese Islands, Mozambique & -25.9 \\
\hline Thalassia testudinum & Hall et al. [60] & 197 & Florida Bay, USA & 25.14 \\
\hline Thalassia testudinum & Tamasko and Hall [64] & 56 & Charlotte Harbour, Florida, USA & 26.9 \\
\hline Thalassia testudinum & Galegos et al. [65] & 30 & Cancún, Mexico & 21 \\
\hline Thalassia testudinum & Enríquez and Pantoya-Reyes [67] & 9 & Puerto Morales, Cancún, Mexico & 20.87 \\
\hline Thalassia testudinum & Paynter et al. [68] & 3 & Punta Cahuita, Costa Rica & 9.7 \\
\hline Thalassia testudinum & Kaldy and Dunton [66] & 20 & Laguna Madre, Texas, USA & 26.13 \\
\hline Thalassia testudinum & Medina-Gómez et al. [69] & 6 & Bahia de la Ascencion, Mexico & 19.7 \\
\hline Zosterajaponica & Lee et al. [49] & 18 & Dadae Bay, Geoje Island, Korea & 34.43 \\
\hline Zosterajaponica & Ruesink et el. [55] & 20 & Stackpole, Willapa Bay, Washington, USA & 46.59 \\
\hline Zosterajaponica & Ruesink et el. [55] & 20 & Oysterville, Willapa Bay, Washington, USA & 46.54 \\
\hline Zosterajaponica & Ruesink et el. [55] & 20 & Nahcotta, Willapa Bay, Washington, USA & 46.49 \\
\hline Zostera marina & Lee et al. [49] & 18 & Dadae Bay, Geoje Island, Korea & 34.43 \\
\hline Zostera marina & Olesen and Sand-Jensen [62] & 32 & North America, Europe \& Japan & 30 to 56 \\
\hline Zostera marina & Kim et al. [57] & 46 & Seomjin Estuary, South Korea & 34.9 \\
\hline Zostera marina & Krause-Jensen et al. [56] & 766 & Oresund strait & 55.6 \\
\hline Zostera marina & Möller et al. [61] & 9 & Prangli, Baltic Sea, Finland & 59.63 \\
\hline Zostera marina & Möller et al. [61] & 7 & Sõru, Baltic Sea, Finland & 58.69 \\
\hline Zostera marina & Möller et al. [61] & 2 & Saarnaki, Baltic Sea, Finland & 58.80 \\
\hline Zostera marina & Möller et al. [61] & 3 & Ahelaid, Baltic Sea, Finland & 58.74 \\
\hline Zostera marina & Ruesink et el. [55] & 4 & Stackpole, Willapa Bay, Washington, USA & 46.59 \\
\hline Zostera marina & Ruesink et el. [55] & 5 & Oysterville, Willapa Bay, Washington, USA & 46.54 \\
\hline Zostera marina & Ruesink et el. [55] & 5 & Nahcotta, Willapa Bay, Washington, USA & 46.49 \\
\hline Zostera marina & Jones et al. [80] & 34 & British Isles and Nothern Ireland & 50.6 to 54.6 \\
\hline Zostera nolti & Cabaço et al. [43] & 276 & Ria Formosa, Portugal & 37.10 \\
\hline Zostera nolti & Cabaço et al. [45] & 16 & Ria Formosa, Portugal & 37.10 \\
\hline Zostera noltii & Garcia-Marín et al. [46] & 13 & Ria Formosa, Portugal & 37.1 \\
\hline Zostera noltii & Garcia-Marín et al. [46] & 13 & Huelva, Spain & 37.2 \\
\hline Zostera noltii & Garcia-Marín et al. [46] & 13 & Cadiz, Spain & 36.5 \\
\hline Zostera noltii & Plus et al. [48] & 54 & Thau Lagoon & 43.4 \\
\hline Zostera noltii & Plus et al. [63] & 22 & Thau Lagoon & 43.4 \\
\hline
\end{tabular}

the $\log _{10} \mathrm{~B}$ vertical axis is the same angle between the seagrass IBL and the $\log _{10} \mathrm{D}$ horizontal axis (Fig. 2). Hence, $\theta=\operatorname{arctg}\left(\left|\beta_{1}\right|\right)$, which in the seagrass case corresponds to $\theta=0.413$. The perpendicular distance is the cosine of $\theta$, in the case of seagrass $\cos \theta=0.916$, multiplied by the $B$ vertical distance: $d_{\text {grass }}=\left(\log _{10} \dot{B}-\log _{10} \mathrm{~B}\right) \cdot \cos \theta$. The vertical distances require the observed $\log _{10} \mathrm{~B}$ and the estimated $\log _{10} \dot{\mathrm{B}}=\beta_{0}+\beta_{1} \cdot \log _{10} \mathrm{D}$. 


\section{Additional data}

The biomass-density data was correlated with additional biotic and abiotic data to test which factors may determine seagrasses demography. These additional data were taken from the studies from which the biomass-density data was taken (Table 1). The full dataset is provided as additional files.

Lee et al. [49] compared the demography of the Zostera marina and Zostera japonica native to the South Korean coast. The Zostera marina occupied the subtidal whereas the Zostera japonica occupied the intertidal. Sampling occurred from July 2001 to July 2002, and retrieved a set of biotic variables related to the populational, morphometric and ecophysiological properties of the seagrasses, and another set of abiotic variables characterizing the water properties, sediment properties and light regime.

Plus et al. [48] studied factors determining the primary production of Zostera noltii in the Thao lagoon from July 1996 to August 1998. The biotic variables retrieved included biomass and density. The abiotic variables included water temperature, salinity, photosynthetic active radiation (PAR) at the surface and on the bottom, light extinction coefficient, and the concentrations of $\mathrm{NH}_{4}{ }^{+}, \mathrm{NO}_{2}{ }^{-}, \mathrm{NO}_{3}{ }^{-}$and $\mathrm{PO}_{4}{ }^{3-}$.

Stands of Zostera noltii were followed in the Ria Formosa lagoon system in southern Portugal at four locations along a pollution gradient [45]. Site 1 was the closest to the wastewater treatment plant (more polluted-270 $\mathrm{m}$ away). At the opposite extreme, site 4 was the farthest from the wastewater treatment plant (little polluted-1500 $\mathrm{m}$ away and located in the main channel). All sites were simultaneously assessed during July 2001 (summer), November 2001 (autumn), February 2002 (winter) and May 2002 (spring). To this data we added data from the $Z$. noltii studied by Plus et al. [48] in the Thau Lagoon.

Aiming for an indicator of water quality and ecosystem health, Garcia-Marín et al. [46] developed the ZoNI index from compiled data for intertidal $Z$. noltii stands from the southern Iberian Peninsula. Five stands were sampled in the summer of 2010 in Ria Formosa, south Portugal, three of them assumed under normal conditions (R1, $\mathrm{R} 2$ and R3) and two of them impacted by extreme pollution from urban effluents (I1 and I2). Three stands were sampled both in Huelva ( $\mathrm{H} 1, \mathrm{H} 2$ and $\mathrm{H} 3)$ and in Cádiz (C1, C2 and C3), south Spain, during the summers of 2009-2011. Biotic variables included biomass, density, and other populational, morphometric and biochemical characteristics. Abiotic variables included ammonium, nitrate and phosphate concentrations, and the first principal component (PC1) extracted from a principal components analysis (PCA) synthesized the nutrients general dynamics.

\section{Results}

Similarly to algae and terrestrial plants, seagrasses also had their specific biomass-density boundary (Fig. 3). With a slope of -0.438 and an intercept of 4.569 , the seagrass boundary (IBL) placed far below that of the plant and algae boundaries. This lower placement was mainly due to the lower B-axis intercept. Below their own IBL, seagrasses often showed a positive correlation between their biomass and shoot density, while differentiating among themselves by occupying different bands of the biomass-shoot density spectra (Figs. 3 and 4). The five best efficiencies observed for each species showed that different seagrasses have different maximum efficiencies of space occupation (Fig. 5a). Permutation tests (a class of non-parametric ANOVA where the null hypothesis is simulated by randomly redistributing the data) with 10,000 replications showed that these maximum efficiencies were significantly different $(\mathrm{p}=0.0001$, d.f.error $=40$, d.f. groups $=7$ ).

Stands of Z. marina and Z. japonica at Dadae Bay showed similar biomasses, though $Z$. japonica achieved this under much higher densities of smaller shoots (shown in Fig. 3), resulting in a much better space occupation efficiency (Fig. 5b). The Dadae Bay situation seems to be case-specific, suggesting the occurrence of something particular, as the worldwide trend is for both species to show similar efficiencies of space occupation (Fig. 5a).

The efficiency of space occupation by Zostera marina in the Baltic and by Posidonia sinuosa in Western Australia decreased with depth (Fig. 6). For the P. sinuosa in Western Australia a seasonal trend was also observed where the efficiency of space occupation increased in the winter and decreased in the summer (Fig. 6). This seasonal pattern opposes the pattern observed for the other species and is presented as follows.

The $d_{\text {grass }}$ metric confirmed the general seagrass seasonality but also highlighted regional differences (Fig. 7). The seagrasses from higher latitudes within the northern hemisphere, namely Cymodocea nodosa and the Zostera spp., peaked their efficiency of space occupation during the spring-summer and reached the low point during the winter. Located closer to the equator, the Halodule wrightii stands in the northern hemisphere peaked during June-September (summer). One of the stands located in the southern hemisphere peaked during November-January (summer) whereas the other slightly delayed its peak to the summerautumn. Concomitantly with the seasonal dynamics, the $d_{\text {grass }}$ also discriminated between stands at different locations experiencing different environments. This was particularly evident in the $C$. nodosa and the $H$. wrightii populations. 


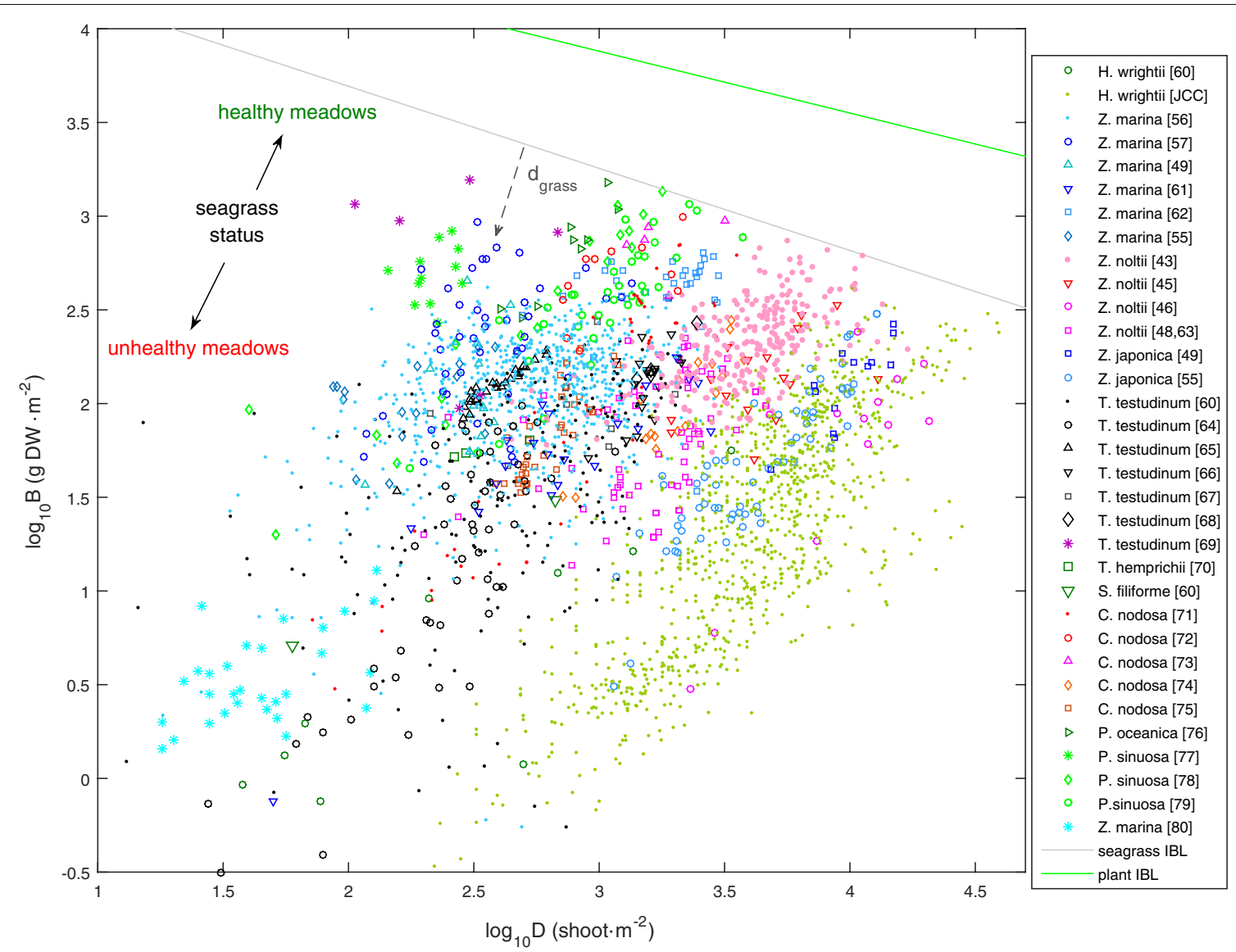

Fig. 3 Seagrass biomass-shoot density relations worldwide. Biomass (B) and shoot density (D) of seagrasses, their interspecific boundary line (IBL) given by $\log _{10} B=4.569-0.438 \cdot \log _{10} D$, and stands' distances to the IBL $\left(d_{\text {grass }}\right)$. Status of seagrass meadows was labelled as 'healthy seagrass meadows' inhabiting favourable environments, and 'unhealthy seagrass meadows' inhabiting less favourable environments

The effects of ammonium and phosphate on the efficiency of space occupation peaked at intermediate concentrations, mimicking the dynamics generally reported for the effects of these nutrients on the growth rates of seagrasses (Fig. 8). The optimal nutrient concentrations for Z. noltii in Ria Formosa were much higher than in the Thau Lagoon. The $Z$. noltii's most efficient space occupation at Ria Formosa were found at the sampling sites located at intermediate distances from the wastewater treatment plant. The concentrations of other nutrients showed no effects over the $Z$. noltii stands in the Thau Lagoon and in Ria Formosa (Fig. 8).

In the Thau lagoon, temperature and PAR at the bottom (i.e., at stand level) were the fundamental factors governing $Z$. noltii's efficiency of space occupation. The $\mathrm{d}_{\text {grass }}$ was better fit to the congregation of a quadratic function for temperature and another quadratic function for PAR (Eq. 1), although the resulting forth order term was disregarded from the numerical estimation of coefficients.

$$
d_{\text {grass }}=\left(a_{0}+a_{1} T+a_{2} T^{2}\right)\left(b_{0}+b_{1} P A R+b_{2} P A R^{2}\right)
$$

The efficiency of space occupation (i.e., $d_{\text {grass }}$ ) mimicked the photosynthetic and growth responses to irradiance as modelled by the classical photosynthesisirradiance (P-I) curves. Hence, given a fixed temperature, there was an optimal PAR above and below which the space occupation deteriorated i.e., $d_{\text {grass }}$ increased (Fig. 9). Concomitantly, given a fixed PAR, there was an optimal temperature above and below which the space occupation deteriorated (Fig. 9). The optimal temperature and optimal PAR were negatively correlated-i.e., as temperature increased its correspondent optimal PAR decreased-suggesting that temperature had a positive effect on the photosynthetic efficiency. 


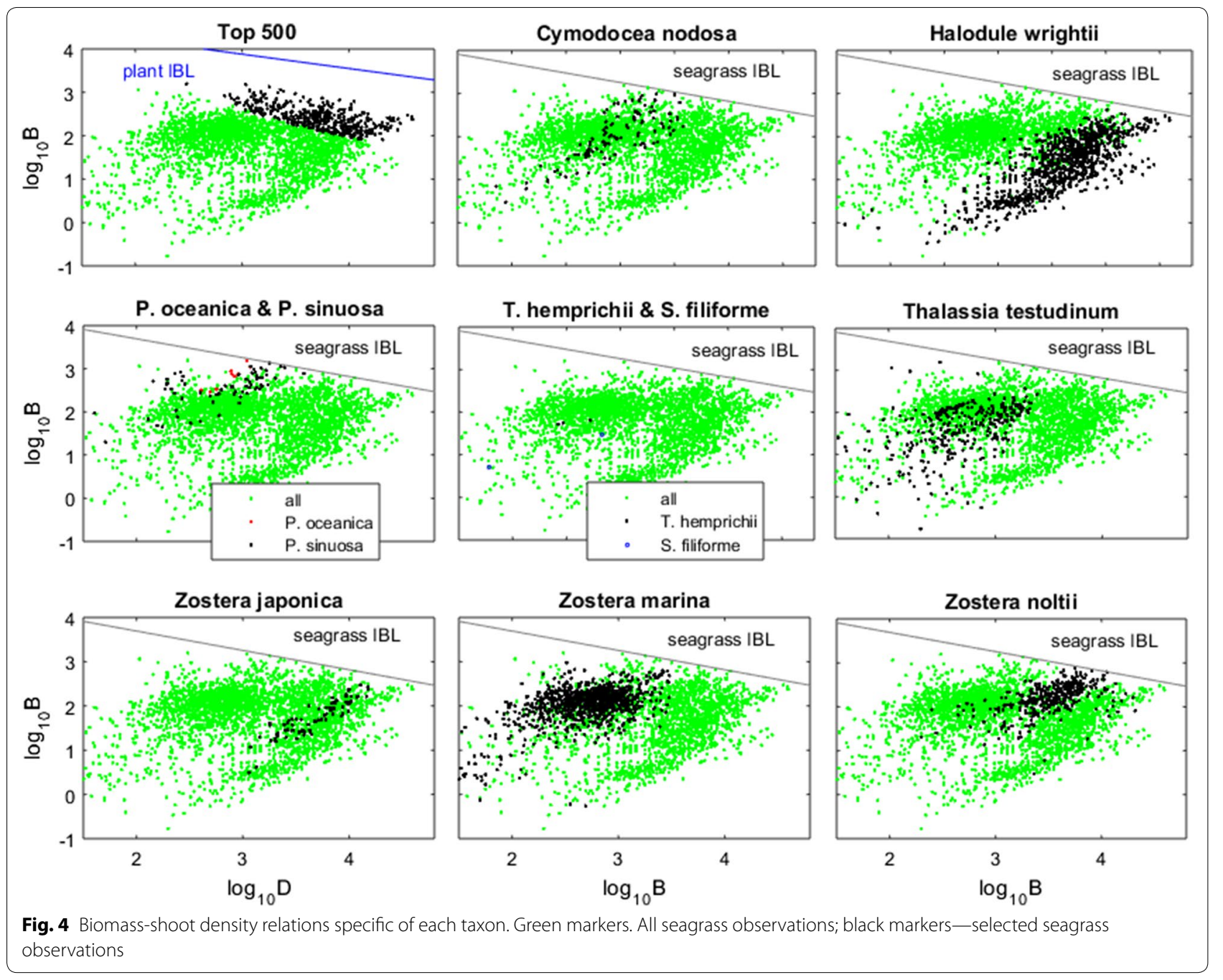

The ZoNI index correlated remarkably well with the $\mathrm{d}_{\text {grass }}(\mathrm{r}=0.92$, see Additional file 1: Fig. S1). Correlating the $\mathrm{d}_{\text {grass }}$ with the abiotic data from Garcia-Marin et al. [46] (Fig. 10), it was found that Huelva's stand 1 (H1) during 2011 showed an extremely weak space occupation as a consequence of some unaccounted factor, and hence was disregarded. The analysis on the remaining stands revealed that the fundamental constrain to $Z$. noltii space occupation was phosphate pollution above $0.5 \mu \mathrm{M}$. The polluted stands (I1 and I2) correlated phosphate concentrations above this threshold with an inefficient occupation of space (i.e., very large $d_{\text {grass }}$ ). All other stands were below this phosphate concentration threshold and showed much smaller and similar $d_{\text {grass }}$. Ammonium and nitrate had no influence on the inefficient space occupation by the polluted sites. In fact, these sites were even within the group of stands with lower nitrate concentrations. The correlation between $\mathrm{d}_{\text {grass }}$ and the nutrients PC1 was largely contaminated by the noise introduced in the nutrients $\mathrm{PC} 1$ by the presence of the ammonium and nitrate variables.

\section{Discussion}

The lower placement of the seagrass IBL-due to its lower B-axis intercept-shows that seagrasses are poor occupiers of space, both compared to terrestrial plants, with whom they share taxonomic similarities, and when compared to algae, with whom they share the marine environment. The classical biomass-density models $[1,13]$ determine that one of the causes for a lower intercept is less volume exploited per unit plant stand surface (the other being less biomass per used volume). There are three possible causes for this event:

i. Wasted available volume due to short shoot heights, and thus also smaller height-to-width ratio. This constitutes vertical waste; 

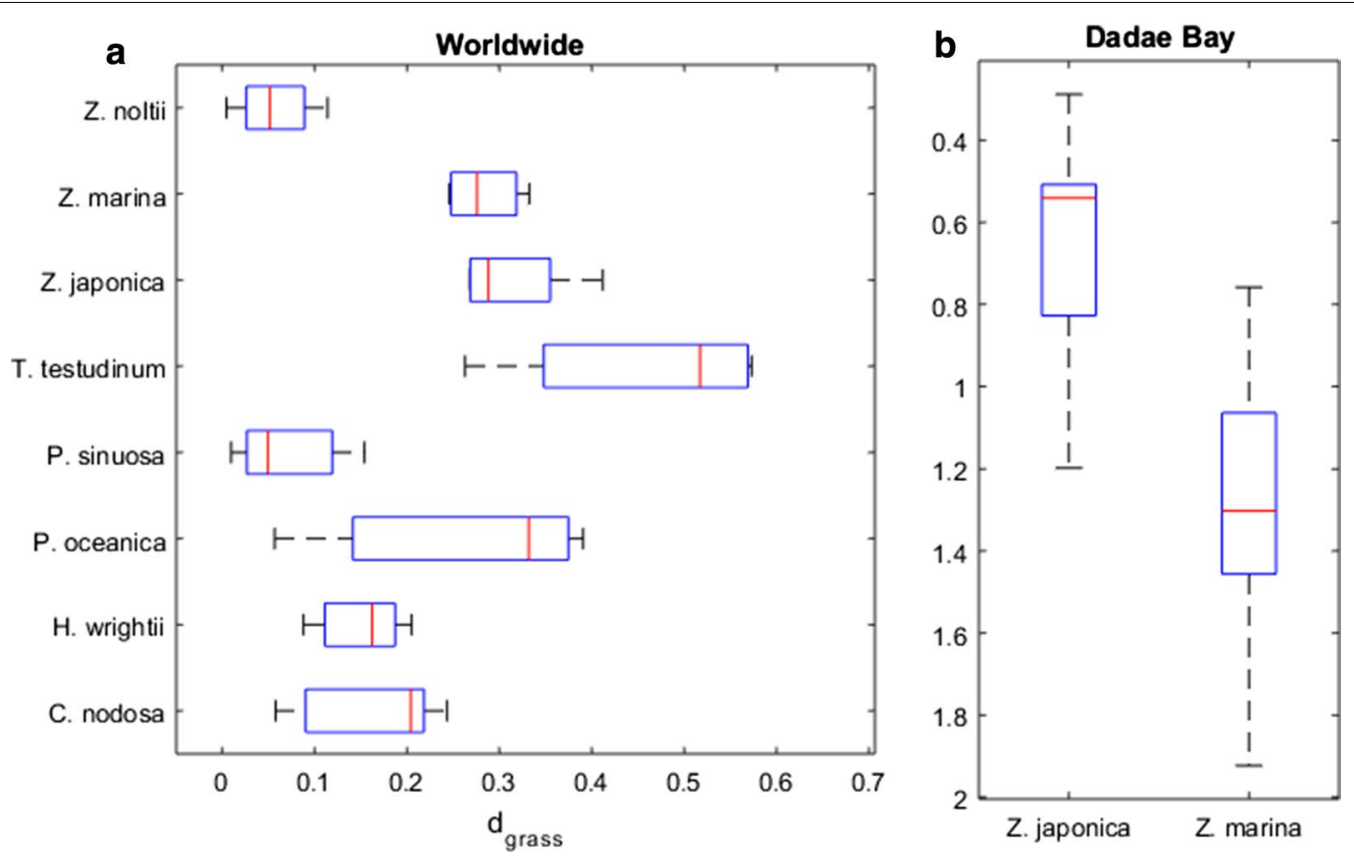

Fig. 5 Seagrass discrimination by efficiency of space occupation. Each stands'distances to the seagrass IBL $\left(d_{\text {grass }}\right)$ is used as a measure of this efficiency. This measure was compared $\mathbf{a}$ among taxa worldwide and $\mathbf{b}$ for the case study of Dadae Bay [49]. Box and whiskers represent the quartiles of the sample distribution

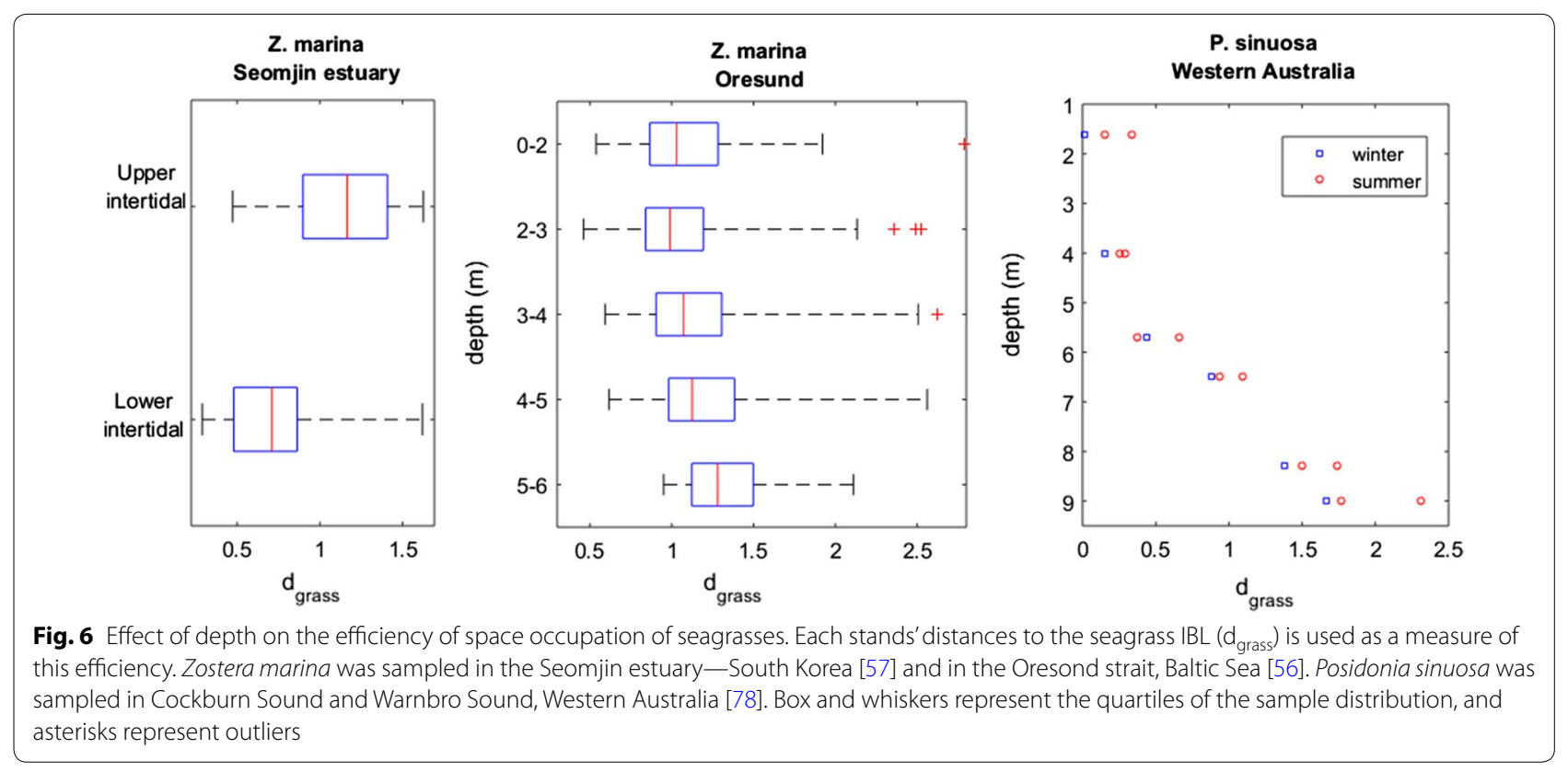

ii. Wasted available volume due to internode lengths larger than shoot widths. This constitutes horizontal waste that is fixed along the vertical axis; iii. Wasted available volume due to shoot shape, as was similarly argued for the crown shape of trees $[12,50]$. This constitutes horizontal waste that is variable along the vertical axis. 

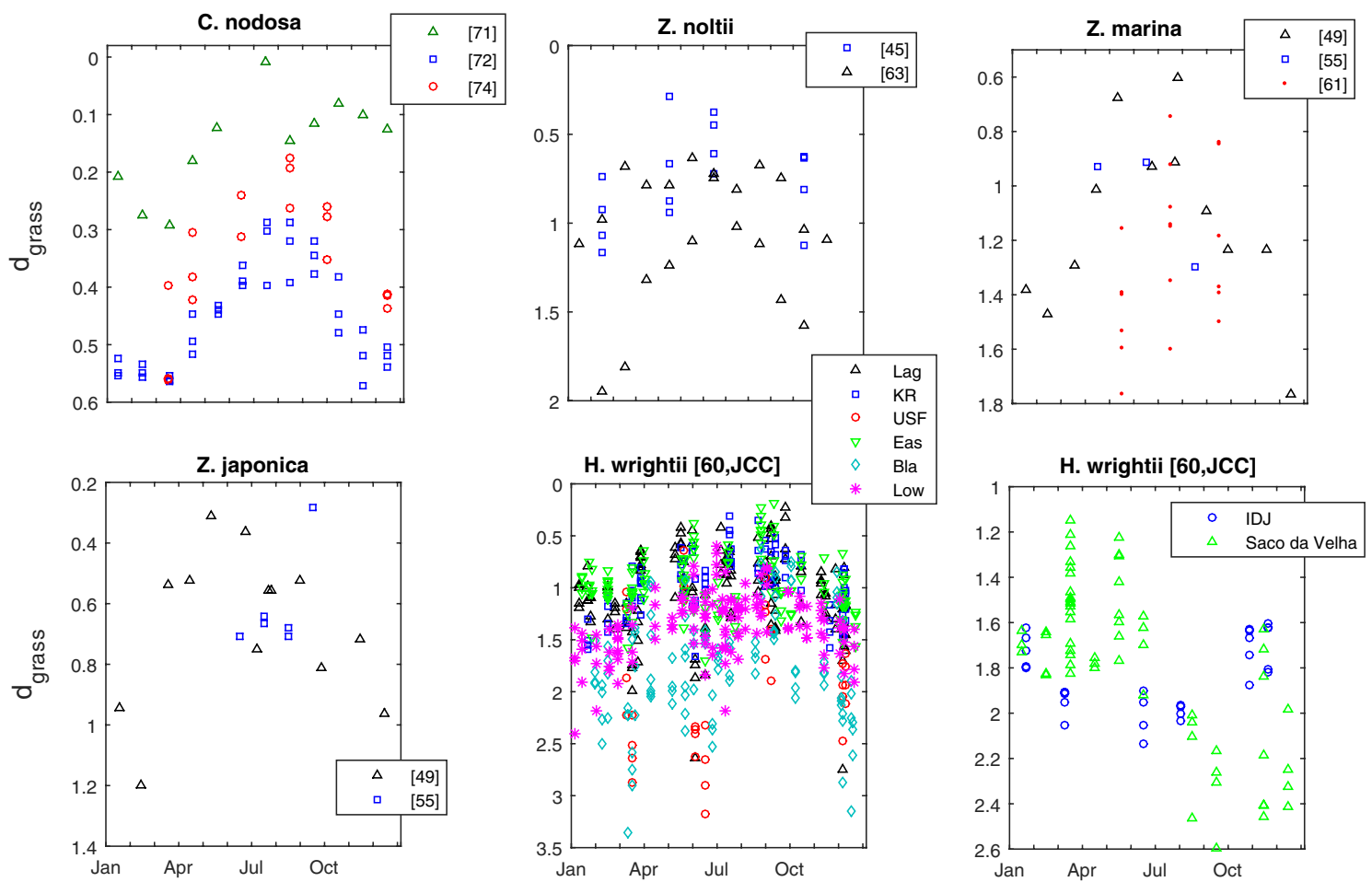

Fig. 7 Seasonality of the seagrass efficiency of space occupation. The seagrass efficiency of space occupation is evaluated from the distance to the seagrass IBL $\left(d_{\text {grass }}\right)$

The scarcity of data with the required metrics did not allow generalization as to which aspects of seagrass allometry mentioned above affect their efficiency of space occupation. Nevertheless, the hypothesis (i) seems the most likely as seagrass canopies are relatively short when compared to their terrestrial counterparts. In permanently immersed stands, the shoots usually do not extend to fully occupy the available height (to sea-surface). Hence, it is unlikely that it is the sea-surface that usually acts as a barrier for vertical growth of seagrasses. A possible explanation for the height limitation comes from the fact that seagrasses generally lack secondary metabolites with anti-fouling properties frequently found in algae and hence need to avoid build-up of epiphytes which reduce light and nutrient uptake. They do so by using a basal meristem and changing leaves regularly, which puts a limit on both leaf length and biomass accumulation. The hypothesis (ii) about shoots narrower than internode length is unlikely, particularly if the stands' have intermingled genets and/or branched rhizomes. Relative to hypothesis (iii) land crown shapes are less efficient at occupying space due to the structural adaptations of terrestrial plants for gravity. In water, less constrained by gravity, algae can use more efficient shapes, ultimately leading to an algae IBL placed above that of plants [12].
Immersed seagrasses are similarly less constrained by gravity, but shoot shape is constrained by leaf number per shoot and leaf width, which are relatively non-plastic seagrass variables, so space occupation depends on leaves elongating and presenting themselves horizontally. It should also be noted that seagrasses may not benefit as much from the support offered by the aqueous medium as seaweeds do because they still present some limiting structural tissue of their terrestrial ancestors (see Creed et al. [12] on this topic). Compared to their terrestrial counterparts, in these marine plants there may be a trade-off between the benefit of reduced investment in structural tissue and disadvantage of increased light attenuation. Despite their inefficient space occupation, seagrasses can dominate the intertidal and shallow subtidal in estuarine and lagoon systems, leading to the conclusion that the efficiency of space occupation is not the characteristic that concedes their ecological advantage over their algal competitors. As most algae need hard substrate to attach to, the fact that seagrasses can colonize soft sandy bottoms is the most likely explanation for their ecological advantage.

Different seagrasses showed different maximum efficiencies of space occupation. However, these estimates were very sensitive to the placement of the seagrass 


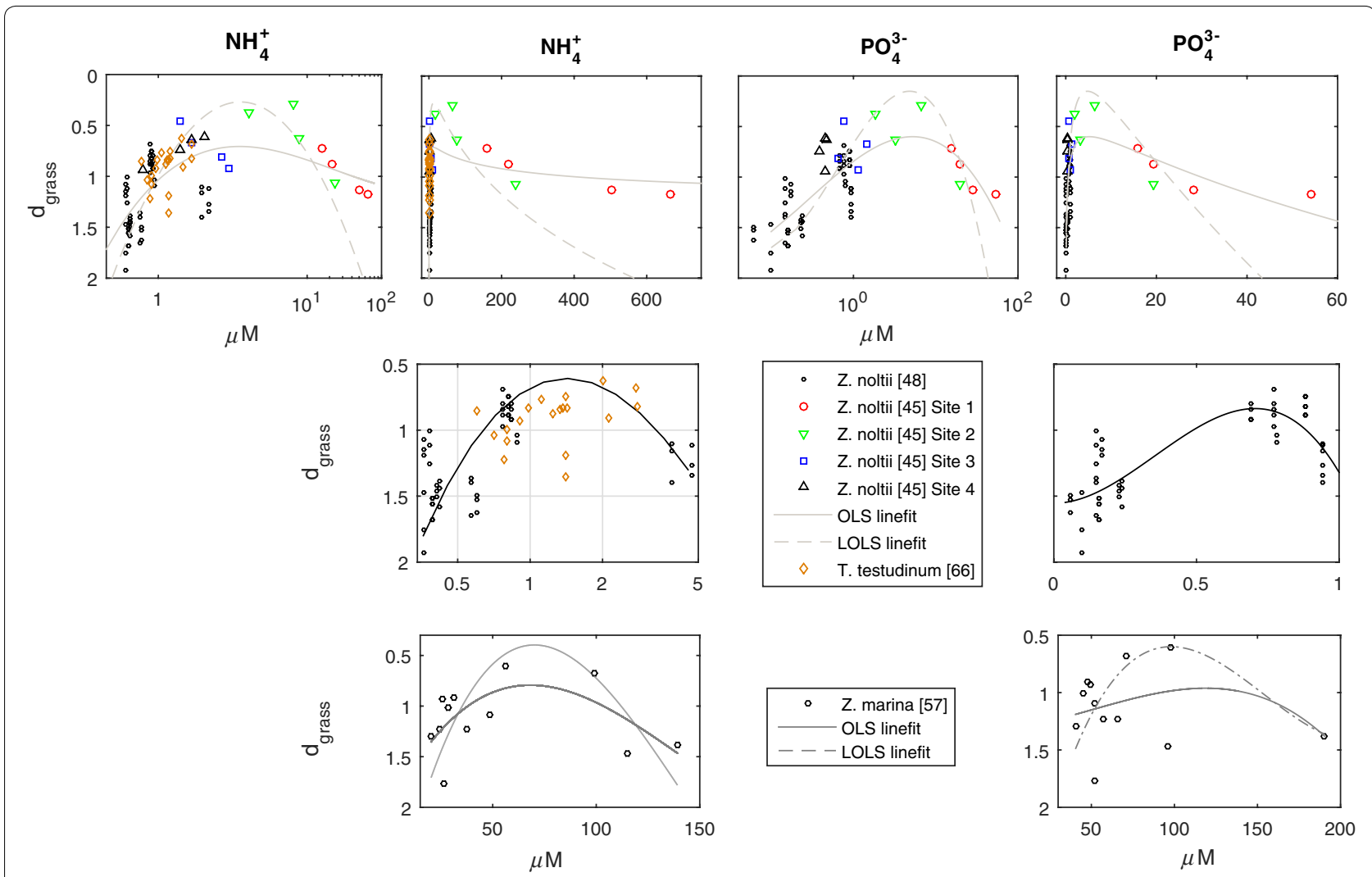

Fig. 8 Effects of amonium and phosphate on the efficiency of space occupation ( $\mathrm{d}_{\text {grass }}$ ) by Zostera noltii and Thalassia testudinum stands. Stands in Ria Formosa are in a gradient of closeness to a wastewater treatment plant, and measured seasonally. Site 1 was the closest and more polluted and site 4 the furthest away and least polluted [45]. Stands in the Thau Lagoon sampled by Plus et al. [48]. T. testudinum stands sampled by Kaldy and Dunton [66]. Model fits by Ordinary Least Squares (OLS) and Linear-in-the-parameters Oblique Least Squares (LOLS) [81]. The LOLS was fit by the new debuged software provided as Additional file 3

IBL, which in turn was estimated based only on ten species for which data are available. Furthermore, in the case of $Z$. japonica it is possible that its maximum efficiency, estimated lower than many other species, results from insufficient sampling. On the contrary, $H$. wrightii was sampled at 25 stations scattered along both tropical bands in the northern and southern hemisphere totalling 1005 observations, whereas $Z$. marina was sampled at 23 stations scattered worldwide and totalling 908 observations. Hence, although we should be cautious analysing these results, it seems safe to say that $Z$. noltii, P. sinuosa, $H$. wrightii, and $C$. nodosa are able to occupy space more efficiently than $T$. testudinum, $Z$. japonica and $Z$. marina.

Different seagrasses occupy different bands of the biomass-shoot density spectra, suggesting conditional differentiation of co-occurring seagrass species. As an example, $Z$. marina co-occurs with $Z$. noltii in the Atlantic and with $Z$. japonica in the Pacific Ocean; where it occupies a biomass-density band conspicuously different from those of its competitors. Within their respective bands, seagrass species tend to show a positive biomass-density correlation contrasting with the negative correlation typical of non-clonal plants and algae. This positive correlation typical of seagrasses is a consequence of their clonality [28] and suggestive of the growth-form plasticity already demonstrated in clonal terrestrial plants [51-53] and clonal algae [54]: the high shoot densities match the phalanx growth-form suited to dominate favourable environments [51]. On the other hand, when the environment is not favourable, the low shoot densities match the guerrilla growth-form allowing for faster dispersion in the search for better locations [51]. By mimicking the positive biomass-density correlation of seagrasses, the perpendicular distance to the seagrass IBL (i.e., the $\mathrm{d}_{\text {grass }}$ ), besides being an index for the efficiency of space occupation, is also an index for the trade-off in clonal-growth-form plasticity: small $\mathrm{d}_{\text {grass }}$ corresponding to high efficiencies and phalanx growth, and large $d_{\text {grass }}$ corresponding to low efficiencies and guerrilla growth. This dynamic may seem paradoxical at first sight: when the environment is sub-optimal, adopting the guerrilla growth form gets the stand further 

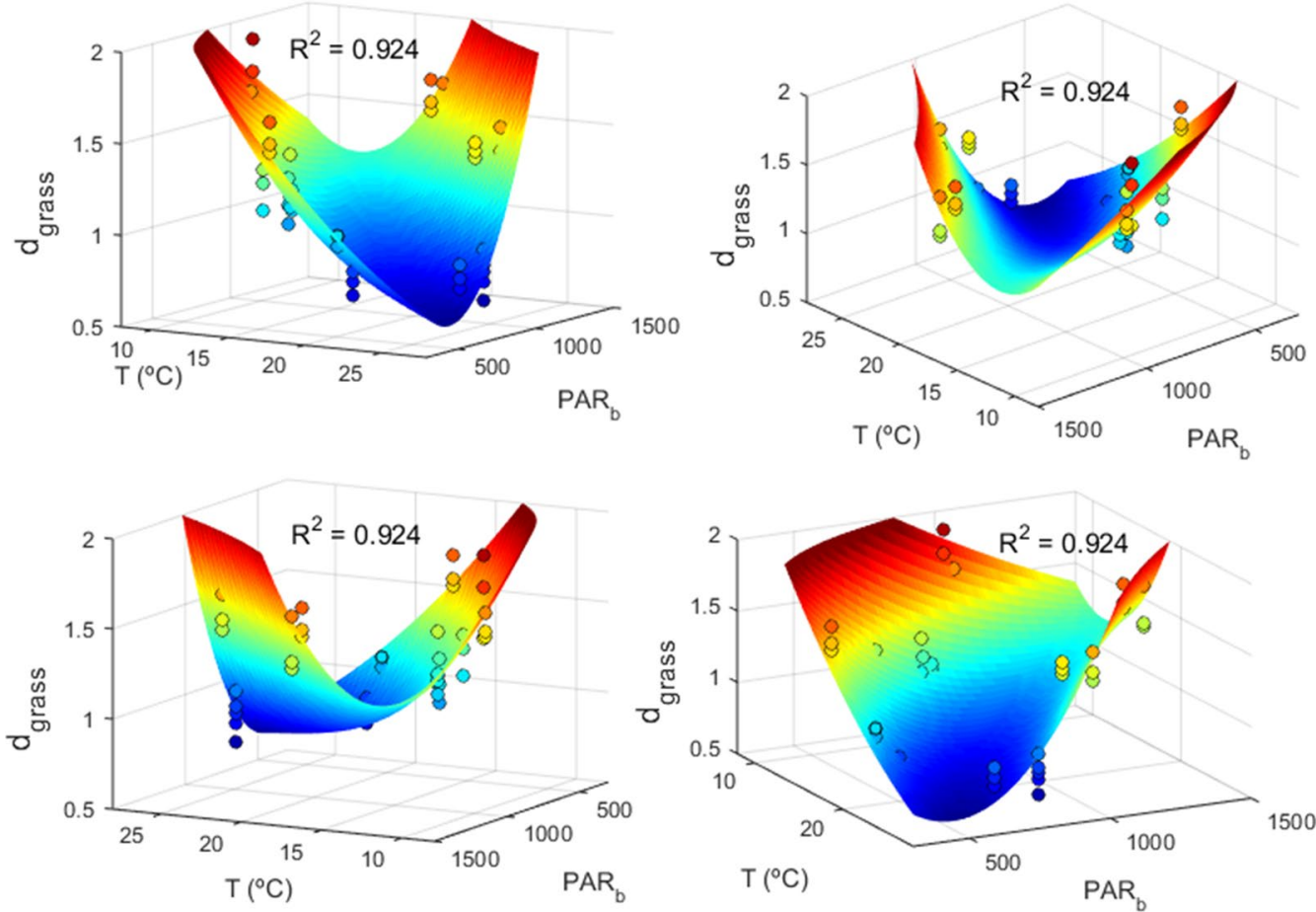

Fig. 9 Abiotic drivers of the efficiency of space occupation $\left(\mathrm{d}_{\text {grass }}\right)$ by Zostera noltii in the Thao lagoon. The $\mathrm{d}_{\text {grass }}$ of stands sampled by Plus et al. [48] is dependent from temperature $(T)$ and photosynthetic active radiation at the bottom (PAR $)$. The $d_{\text {grass }}$ fit was performed by Ordinary Least Squares (OLS). All four panels are different perspectives of the same 3D plot showing the surface fit by Eq. (1)
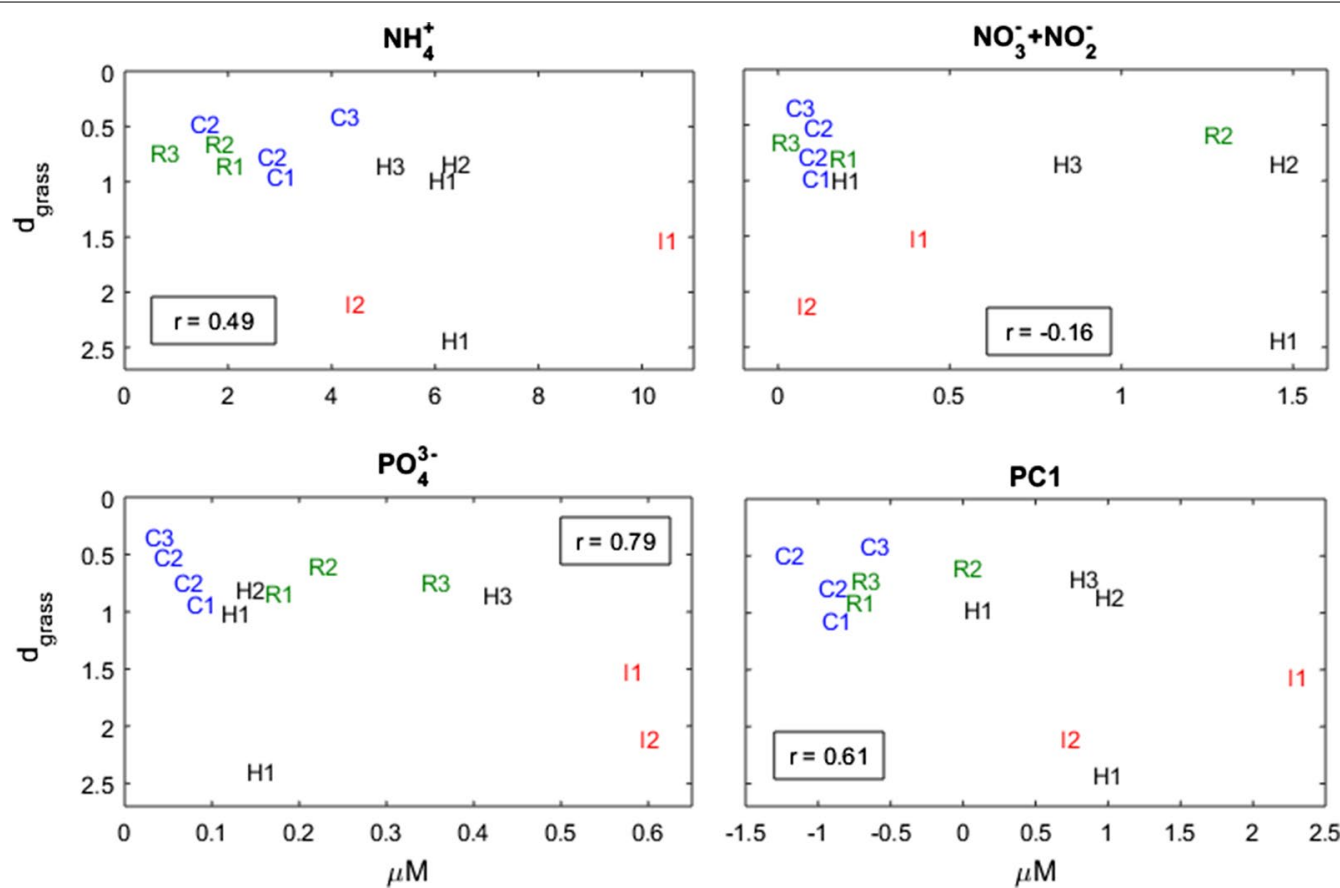

Fig. 10 The $d_{\text {grass }}$ of Zostera noltii stands in southern Iberia. Stands from Ria Formosa, Portugal in natural (R) or highly impacted (I) locations, from Huelva $(\mathrm{H})$ and from Cádiz (C). Correlation coefficients ( $r$ ) estimated disregarding $\mathrm{H} 1$ sampled during 2011 
away from the efficient space occupation, and thus more susceptible to competitors. On the other hand, when the environment is favourable, the phalanx growth form allows for the stand to reach the maximum efficiency more quickly, but at the cost of decreasing the stand biomass potential. It intuitively seems advantageous when competing with other seagrasses but not when competing with algae that have much higher space occupation efficiencies (see Creed et al. [12] for the algal IBL). Regarding this unorthodox phalanx strategy, we highlight three aspects:

i. Seagrasses avoid competition from algae by colonizing a substrate to which most algae cannot attach and grow;

ii. Thomsen et al. [38] found that small seagrasses (consequently, with lower biomasses and higher densities) are more vulnerable to their algae competitors;

iii. The advantage of reaching the boundary more quickly may also be related to complementary aspects. For instance, reaching the maximum biomass quicker may release resources for other aspects of seagrass development such as sexual reproduction, rhizome storage or growth at the edges of the stand.

The $Z$. marina and $Z$. japonica stands at Dadae Bay [49] are a good example of how seagrasses make use of phenotypic plasticity to adapt to the abiotic and biotic conditions, and how this affects their efficiency of space occupation. Both species had equally long leaves but the $Z$. marina leaves were wider. Furthermore, $Z$. marina showed a higher leaf production rate, leading to a higher number of leaves per shoot [49]. The consequent larger biomass per shoot of $Z$. marina relative to $Z$. japonica is a global attribute. However, at Dadae Bay it was fully compensated by the higher shoot density of $Z$. japonica, a consequence of its shorter internode length [49] and/or intermingled genets, and which led $Z$. japonica to occupy space more efficiently. The $Z$. japonica in Dadae Bay occupied the intertidal, which is its preferred environment $[49,55]$. Hence, this stand adopted a phalanx growth-form whose high density and closeness to the IBL disables the colonization by its seagrass competitors. As for Z. marina, the application of the $d_{\text {grass }}$ to the data taken from the studies by KrauseJensen et al. [56] and Kim et al. [57], demonstrated that, worldwide, $Z$. marina is more efficient in the lower intertidal. However, in Dadae Bay the lower intertidal was already occupied by $Z$. japonica. Hence, $Z$. marina was relegated to the shallow subtidal where it adopted a guerrilla growth-form whose focus is on spreading to its preferred neighbouring lower intertidal. Contrasting the phalanx grow form of $Z$. japonica with the guerrilla grow form of $Z$. marina, the $Z$. marina internode length was on geometric average 2.5 times longer than that of Z. japonica while its reproductive effort was approximately 3 times higher (Additional file 2: data and Lee et al. [37]).

The efficiency of space occupation revealed itself to be an outstanding tool for understanding aspects of seagrass ecology. Based on this efficiency, we developed the $d_{\text {grass }}$ metric, whose application to seagrasses worldwide enabled us to generalize regarding seasonality, their depth profiles, and their response to nutrients, light and temperature. We have already done the same for algae, developing the $d_{\text {algal }}$ metric and applying it with success [12]. In the case of seagrasses, the $d_{\text {grass }}$ seasonality matched the generalized summer peaks of seagrass growth and Photosynthesis-Irradiance (P-I) curve parameters [37]. The effects of ammonium and phosphate concentrations on $\mathrm{d}_{\text {grass }}$ mimicked the dynamics generally reported for the effects of these nutrients over the growth rates: very low concentrations were detrimental as autotrophs need nutrients to survive and grow. However, at high concentrations these molecules became toxic, shifting their role from nutrients to pollutants [39-41, 43-46]. The optimal nutrient concentrations for Z. noltii in Ria Formosa higher than in the Thau Lagoon suggested that some additional factor was influencing the optimal points. The $Z$. noltii's most efficient space occupations in Ria Formosa located at intermediate distances from the wastewater treatment plant revealed that the wastewater often had a beneficial effect over those patches by raising the ammonium and phosphate concentrations to optimal values. The $Z$. noltii's $\mathrm{d}_{\text {grass }}$ response to irradiance mimicked a P-I curve with photo-inhibition above the optimal irradiance, as has been reported for seagrasses [37] and for $Z$. noltii in particular [58]. Concomitantly, the $Z$. noltii's $\mathrm{d}_{\text {grass }}$ response to temperature mimicked the previously reported parabola-type relation between seagrass growth and temperature [37].

We take the remarkable correlation of the ZoNI index with the $d_{\text {grass }}$ as evidence that both are good indicators of the health of seagrass meadows. Monitoring seagrass health has been proposed for coastal water quality assessment [43-47]. The development of an ecological indicator relying exclusively on the biomass-density relation of seagrasses has been previously attempted, unsuccessfully $[47,59]$. At that time, the existence of a seagrass IBL and the fact that the efficiency of space occupation is a fundamental aspect of seagrass ecology were unknown. Hence, back then it was impossible for the respective authors to succeed in their objective. Nevertheless, our new findings demonstrate that this is a useful concept and tool, which 
we put back on track reformulated around the efficiency of space occupation. We present three strong arguments for its future application:

i. Its simplicity The $\mathrm{d}_{\text {grass }}$ only requires two variables-the stand's above-ground biomass and shoot density - which are also the easiest to retrieve and describe well habitat availability and complexity;

ii. Its generality It is applicable to any seagrass (estimating $\mathrm{d}_{\text {grass }}$ ), any terrestrial plant (estimating $\mathrm{d}_{\text {plant }}$ ) and any algae (estimating $\mathrm{d}_{\text {algal }}$ ), on any location on the planet, and even enables comparisons within and among these three groups. As examples, while the ZoNI is restricted to Z. noltii [46] and the POMI to P. oceanica [44], the $\mathrm{d}_{\text {grass }}$ allows comparisons among all seagrasses. Furthermore, it is possible to compare among seagrasses, algae and plants, estimating their distances to their respective IBLs, namely the $\mathrm{d}_{\text {grass }}, \mathrm{d}_{\text {algal }}$ and $\mathrm{d}_{\text {plant }}$;

iii. Its background The $\mathrm{d}_{\text {grass }}$ is grounded on the biomass-density relations of plants and algae, thoroughly studied since the 1950s with the selfthinning law accolade of "the only generalization worthy of the name law in plant ecology" [2]. It has already performed well when applied to other subjects. Its previous application to worldwide algal data has determined that the efficiency of space occupation in the algae depends on taxonomic group, functional group, clonality and latitude [12]. Its current application to seagrass worldwide has unveiled how it can be used to compare stands and interpret efficiency in light of intrinsic (population dynamics) and extrinsic (eco-physiological) factors.

\section{Conclusions}

The placement of seagrass meadows in the biomass-density plot is limited by their interspecific boundary line (IBL) setting a maximum efficiency of space occupation. Furthermore, species tend to differentiate the bands each occupies in this scatter-plot, which is evidence of their conditional differentiation. The efficiency of space occupation by seagrasses, requiring only the biomass and shoot-density of their stands and measured by their perpendicular distance to the seagrass IBL, revealed a highly useful indicator of their ecological condition. It identified the summer as their most favourable season and the lower intertidal as their preferred depth. It discriminated among locations. It identified which nutrients were in excess, thus acting as pollutants, and beyond which concentrations did these have a deleterious effect over seagrasses. The $d_{\text {grass }}$ was revealed to be a most efficient ecological index with general application and comparable with similar indexes developed for seaweeds and terrestrial plants.

\section{Additional files}

\section{Additional file 1: Fig. S1. Additional figure.}

Additional file 2. The biomass and density presented in 32 studies on 10 seagrass species scattered worldwide. Additional biotic and abiotic variables are also provided depending on their availability from the respective study.

Additional file 3. The LOLS software fitting dgrass to the nutrients data.

\section{Abbreviations}

B: biomass; D: density; $d_{\text {algae: }}$ perpendicular distance to the algae IBL; $d_{\text {grass: }}$ : perpendicular distance to the seagrass IBL; $\mathrm{D}_{\text {plant }}$ : perpendicular distance to the plant IBL; IBDR: interspecific biomass-density relationship; IBL: interspecific boundary line; PAR: photosynthetic active radiation; PCA: principal components analysis; PC1: principal component \#1; POMI: Posidonia oceanica multivariate index; UBDL: ultimate biomass-density Line; w: individual plant weight; ZoNl: Zostera noltii multi-metric index.

\section{Authors' contributions}

W collected the data, developed the models and software, designed and performed the data analysis, interpreted the results and wrote the article. JCC collected the data, interpreted the results and reviewed the article. IEL collected the data and reviewed the article. All authors read and approved the final manuscript.

\section{Author details}

${ }^{1}$ MARETEC, Instituto Superior Técnico, Universidade Técnica de Lisboa, Av. Rovisco Pais, 1049-001 Lisbon, Portugal. ${ }^{2}$ Departamento de Ecologia, Instituto de Biologia Roberto Alcântara Gomes, Universidade do Estado do Rio de Janeiro, Rua São Francisco Xavier 524, Rio de Janeiro, RJ 20559-900, Brazil.

\section{Acknowledgements}

Our gratitude to the researchers who shared their data with us. Their contributions were fundamental for the success of our study.

\section{Competing interests}

The authors declare that they have no competing interests.

\section{Availability of data and materials}

The dataset supporting the conclusions of this article is included within the Additional file 2

\section{Consent to publish}

Not applicable.

\section{Ethics approval and consent to participate}

Not applicable.

\section{Funding}

W and IEL were funded by ERDF Funds of the Competitiveness Factors Operational Programme-COMPETE and national funds of the FCT_-Foundation for Science and Technology under the project UID/EEA/50009/2013. This work was supported by Coordenação de Aperfeiçoamento de Pessoal de Nível Superior (JCC, Ciências do Mar 1137/2010); Fundação Carlos Chagas Filho de Amparo à Pesquisa do Estado do Rio de Janeiro (JCC, FAPERJE-26/111.574/2014 and E26/201.286/2014); and Conselho Nacional de Desenvolvimento Científico e Tecnológico (JCC, CNPq-307117/2014-6). The funders took no part in the design of the study, in the collection, analysis, and interpretation of data, and in writing the manuscript. 


\section{Publisher's Note}

Springer Nature remains neutral with regard to jurisdictional claims in published maps and institutional affiliations.

Received: 28 November 2017 Accepted: 8 October 2018

Published online: 19 October 2018

\section{References}

1. Yoda K, Kira T, Ogawa H, Hozumi K. Self-thinning in overcrowded pure stands under cultivated and natural conditions (Intraspecific competition among higher plants. J Biol Osaka City Univ. 1963;14:107-29.

2. Hutchings MJ. Ecology's law in search of a theory. New Scientist. 1983:98:765-7.

3. Cousens R, Hutchings MJ. The relationship between density and mean frond weight in monospecific seaweed stands. Nature. 1983;301:240-1.

4. Lonsdale WM, Watkinson AR. Plant geometry and self-thinning. J Ecol. 1983;71(285-29):7.

5. White J, Harper JL. Correlated change in plant size and number in plant populations. J Ecol. 1970;58:467-85.

6. Gorham E. Shoot height, weight and standing crop in relation to density of monospecific plant stands. Nature. 1979:279:148-50.

7. Westoby M, Howell J. Influence of population structure on self-thinning of plant populations. J Ecol. 1986;74:343-59.

8. Westoby M. The place of the self-thinning rule in population dynamics. Am Nat. 1981;118:581-7.

9. Weller DE. A reevaluation of the $-3 / 2$ power rule of plant self-thinning Ecol Monogr. 1987;57:23-43.

10. Lonsdale WM. The self-thinning rule: dead or alive? Ecology. 1990;71(4):1373-88

11. Zhang L, Bi H, Gove JH, Heath LS. A comparison of alternative methods for estimating the self-thinning boundary line. Can J For Res. 2005;35:1507-14.

12. Creed J, Norton TA, Caetano D, Vieira VMNCS. Seaweeds surpass plants setting life-on-Earth's limit for biomass concentration. BMC Ecol (submitted)

13. Weller DE. The interspecific size-density relationship among crowded plant stands and its implications for the $-3 / 2$ power rule of self-thinning Am Nat. 1989;133:20-41.

14. Osawa A, Sugita S. The self-thinning rule: another interpretation of Weller's results. Ecology. 1989;70:279-83.

15. Weller DE. The self-thinning rule: dead or unsupported? A reply to Lonsdale. Ecology. 1991;72:747-50.

16. Weller DE. Self-thinning exponent correlated with allometric measures of plant geometry. Ecology. 1987;68:813-21.

17. Morris EC, Myerscough PJ. Self-thinning and competition intensity over a gradient of nutrient availability. J Ecol. 1991;79:903-23.

18. Morris EC. Effect of localized placement of nutrients on root competition in self-thinning populations. Ann Bot. 1996;78:353-64.

19. Morris EC. How does fertility of the substrate affect intraspecific competition? Evidence and synthesis from self-thinning. Ecol Res. 2003;18(3):287-305

20. Scrosati RA. The interspecific biomass-density relationship for terrestrial plants: where do clonal red seaweeds stand and why? Ecol Lett. 2000;3:191-7.

21. Scrosati R. Review of studies on biomass-density relationships (including self-thinning lines) in seaweeds: main contributions and persisting misconceptions. Phycol Res. 2005;53:224-33.

22. Cousens R, Hutchings MJ. The relationship between density and mean frond weight in monospecific seaweed stands. Nature. 1983:301:240-1.

23. Creed JC. Spatial dynamics of a Himanthalia elongate (Fucales, Phaeophyta) population. J Phycol. 1995;31:851-9.

24. Flores-Moya A, Fernández JA, Niell FX. Growth pattern, reproduction, and self-thinning in seaweeds: a re-evaluation in reply to Scrosati. J Phycol. 1997;33:1080-1.

25. Creed JC, Kain JM, Norton TA. An experimental evaluation of density and plant size in two large brown seaweeds. J Phycol. 1998;34:39-52.

26. Arenas F, Fernández C. Size structure and dynamics in a population of Sargassum muticum (Phaeophyceae). J Phycol. 2000;36:1012-20.
27. Steen $H$, Scrosati $\mathrm{R}$ Intraspecific competition in Fucus serratus and F evanescens (Phaeophyceae: Fucales) germlings: effects of settlement density, nutrient concentration, and temperature. Mar Biol. 2004;144:61-70.

28. Hutchings MJ. Weight-density relationships in ramet populations of clonal perennial herbs, with special reference to the $3 / 2$ power law. J Ecol. 1979;67:21-33

29. Westoby M. The self-thinning rule. Adv Ecol Res. 1984;14:167-225.

30. de Kroon H, Kalliola R. Shoot dynamics of the giant grass Gynerium sagittatum in Peruvian Amazon floodplains, a clonal plant that does show self-thinning. Oecologia. 1995;101:124-31.

31. Lazo ML, Chapman ARO. Components of crowding in a modular seaweed: sorting through the contradictions. Mar Ecol Prog Ser. 1998;174:257-67.

32. Scrosati R, Servière-Zaragoza E. Ramet dynamics for the clonal seaweed Pterocladiella capillacea (Rhodophyta): a comparison with Chondrus crispus and with Mazzaella cornucopiae (Gigartinales). J Phycol. 2000;36:1061-8. https://doi.org/10.1046/j.1529-8817.2000.00041.x.

33. Rivera M, Scrosati R. Self-thinning and size inequality dynamics in a clonal seaweed (Sargassum lapazeanum, Phaeophyceae). J Phycol. 2008;44:45-9.

34. Scrosati R. Crowding in clonal seaweeds: does self-thinning occur in Mastocarpus papillatus shortly before stand biomass peaks? Aquat Bot. 2006;84:233-8.

35. Stapel J, Aarts TL, van Duynhoven BHM, de Groot JD, van den Hoogen PHW, Hemminga MA. Nutrient uptake by leaves and roots of the seagrass Thalassia hemprichii in the Spermonde Archipelago, Indonesia. Mar Ecol Prog Ser. 1996;134:195-206.

36. Proulx R, Rheault G, Bonin L, Roca IT, Martin CA, Desrochers L, Seiferling I. How much biomass do plant communities pack per unit volume? PeerJ. 2015:3:e849.

37. Burkholder JM, Tomasko DA, Touchette BW. Seagrasses and eutrophication. J Exp Mar Biol Ecol. 2007:350:46-72.

38. Valiela I, McClelland J, Hauxwell J, Behr PJ, Hersh D, Foreman K. Macroalgal blooms in shallow estuaries: controls and ecophysiological and ecosystem consequences. Limnol Oceanogr. 1997;42:1105-18.

39. Lee K-S, Park SR, Kim YK. Effects of irradiance, temperature, and nutrients on growth dynamics of seagrasses: a review. J Exp Mar Biol Ecol. 2007;350:144-75

40. Thomsen MS, Wernberg T, Engelen AH, Tuya F, Vanderklift MA, Holmer M et al. A meta-analysis of seaweed impacts on seagrasses: generalities and knowledge gaps. PLoS ONE. 2012;7(1):e28595.

41. Brun FG, Olivé I, Malta EJ, Vergara JJ, Hernández I, Pérez-Lloréns J. Increased vulnerability of Zostera noltii to stress caused by low light and elevated ammonium levels under phosphate deficiency. Mar Ecol Prog Ser. 2008;365:67-75.

42. Pergent G, Boudouresque C-F, Dumay O, Pergent-Martini C, WyllieEcheverria S. Competition between the invasive macrophyte Caulerpa taxifolia and the seagrass Posidonia oceanica: contrasting strategies. BMC Ecol. 2008;8:20. https://doi.org/10.1186/1472-6785-8-20.

43. Cabaço S, Machás R, Santos R. Biomass-density relationships of the seagrass Zostera noltii: a tool for monitoring anthropogenic nutrient disturbance. Estuar Coast Shelf Sci. 2007;2007(74):557-64

44. Romero J, Martínez-Crego B, Alcoverro T, Pérez M. A multivariate index based on the seagrass Posidonia oceanica (POMI) to assess ecological status of coastal waters under the water framework directive (WFD). Mar Pollut Bull. 2007:55:196-204

45. Cabaço S, Machás R, Vieira V, Santos R. Impacts of urban wastewater discharge on seagrass meadows (Zostera noltii). Estuar Coast Shelf Sci. 2008;78:1-13.

46. García-Marín P, Cabaço S, Hernández I, Vergara JJ, Silva J, Santos R. Multimetric index based on the seagrass Zostera noltii (ZoNI) for ecological quality assessment of coastal and estuarine systems in SW Iberian Peninsula. Mar Pollut Bull. 2013:68:46-54.

47. Cabaço S, Apostolaki ET, Garcıa-Marín P, Gruber R, Hernandez I, MartınezCrego $B$, et al. Effects of nutrient enrichment on seagrass population dynamics: evidence and synthesis from the biomass-density relationships. J Ecol. 2013;101:1552-62.

48. Plus M, Deslous-Paoli J-M, Dagault F. Factors influencing primary production of seagrass beds (Zostera noltii Hornem.) in the Thau lagoon (French Mediterranean coast). J Exp Mar Biol Ecol. 2001;259:63-84. 
49. Lee SY, Kim JB, Lee SM. Temporal dynamics of subtidal Zostera marina and intertidal Zostera japonica on the southern coast of Korea. Mar Ecol. 2006;27:133-44

50. Purves DW, Lichstein JW, Pacala SW. Crown plasticity and competition for canopy space: a new spatially implicit model parameterized for 250 North American tree species. PLoS ONE. 2007;2(9):e870. https://doi. org/10.1371/journal.pone.0000870.

51. Doust LL. Population dynamics and local specialization in a clonal perennial (Rannunculus repens): 1. The dynamics of ramets in contrasting habitats. J Ecol. 1981;69(3):743-55.

52. Chen X-S, Xie Y-H, Deng Z-M, Hou Z-Y. A change from phalanx to guerrilla growth form is an effective strategy to acclimate to sedimentation in a wetland sedge species Carex brevicuspis (Cyperaceae). Flora Morphol Distrib Funct Ecol Plants. 2011;206(4):347-50.

53. Ye X-H, Yu F-H, Dong M. A Trade-off between Guerrilla and Phalanx growth forms in Leymus secalinus under different nutrient supplies. Ann Bot. 2006;98(1):187-91.

54. Monro K, Poore AGB. The evolvability of growth form in a clonal seaweed. Evolution. 2009;63:3147-57. https://doi.org/10.111 $1 /$ j.1558-5646.2009.00802.x

55. Ruesink JL, Hong J-S, Wisehart L, Hacker SD, Dumbauld BR, HessingLewis $M$, Trimble AC. Congener comparison of native (Zostera marina) and introduced (Z.japonica) eelgrass at multiple scales within a Pacific Northwest estuary. Biol Invasions. 2009. https://doi.org/10.1007/s1053 0-009-9588-z.

56. Krause-Jensen D, Middelboe AL, Sand-Jensen K, Christensen PB. Eelgrass, Zostera marina, growth along depth gradients: upper boundaries of the variation as a powerful predictive tool. Oikos. 2000;91:233-44.

57. Kim JB, Lee W-C, Lee K-S, Park J-I. Growth dynamics of eelgrass, Zostera marina, in the intertidal zone of seomjin estuary, Korea. Ocean Sci J. 2013;48(3):239-50.

58. Peralta G, Pérez-Lloréns JL, Hernández I, Vergara JJ. Effects of light availability on growth, architecture and nutrient content of the seagrass Zostera noltii Hornem. J Exp Mar Biol Ecol. 2002;269:9-26.

59. Vieira VM, Leitão F, et al. Mateus M.Biomass-density data analysis: a comment on Cabaço (2013). J Ecol. 2015;103:537-40.

60. Hall MO, Durako MJ, Fourqurean JW, Zieman JC. Decadal changes in seagrass distribution and abundance in Florida Bay. Estuaries. 1999;22(2B):445-59.

61. Möller T, Kotta J, Martin G. Spatiotemporal variability in the eelgrass Zostera marina L. in the north-eastern Baltic Sea: canopy structure and associated macrophyte and invertebrate communities. Estonian J Ecol. 2014;63(2):90-108.

62. Olesen B, Sand-Jensen K. Biomass-density patterns in the temperate seagrass Zostera marina. Mar Ecol Prog Ser. 1994;109:283-91.

63. Plus M, Chapelle A, Ménesguen A, Deslous-Paoli J-M, Auby I. Modelling seasonal dynamics of biomasses and nitrogen contents in a seagrass meadow (Zostera noltii Hornem.): application to the Thau lagoon (French Mediterranean coast). Ecol Model. 2003;161:213-38.

64. Tomasko DA, Hall MO. Productivity and Biomass of the Seagrass Thalassia testudinum along a Gradient of Freshwater Influence in Charlotte Harbor, Florida. Estuaries. 1999;22(3):592-602.
65. Gallegos ME, Merino M, Marbá N, Duarte CM. Biomass and dynamics of Thalassia testudinum in the Mexican Caribbean: elucidating rhizome growth. Mar Ecol Prog Ser. 1993;95:185-92.

66. Kaldy JE, Dunton KH. Above-and below-ground production, biomass and reproductive ecology of Thalassia testudinum (turtlegrass) in a subtropical coastal lagoon. Mar Ecol Prog Ser. 2000;193:271-83.

67. Enríquez S, Pantoya-Reyes NI. Form-function analysis of the effect of canopy morphology on leaf self-shading in the seagrass Thalassia testudinum. Oecologia. 2005;145:235-43.

68. Paynter CK, Cortés J, Engels M. Biomass, productivity and density of the seagrass Thalassia testudinum at three sites in Cahuita National Park, Costa Rica. Rev Biol Trop. 2001;49(2):265-72.

69. Medina-Gómez I, Madden CJ, Herrera-Silveira J, Kjerfve B. Response of Thalassia Testudinum morphometry and distribution to environmental drivers in a pristine tropical Lagoon. PLoS ONE. 2016;11(10):e0164014.

70. Larsson S. The production of the seagrass Thalassia hemprichii in relation to epiphytic biomass. Degree project for Master of Science in Biology, Department of Marine Ecology, University of Gothenburg, 2009.

71. Duarte CM, Sand-Jensen K. Seagrass colonization: biomass development and shoot demography in Cymodocea nodosa patches. Mar Ecol Prog Ser. 1990;67:97-103.

72. Agostini S, Pergent G, Marchand B. Growth and primary production of Cymodocea nodosa in a coastal lagoon. Aquat Bot. 2003;76:185-93.

73. Cunha AH, Duarte CM. Biomass and leaf dynamics of Cymodocea nodosa in the Ria Formosa lagoon, South Portugal. Bot Mar. 2007;50:1-7.

74. Peduzzi P, Vukovic A. Primary production of Cymodocea nodosa in the Gulf of Trieste (Northern Adriatic Sea): a comparison of methods. Mar Ecol Prog Ser. 1990;64:197-207.

75. Sghaier YR, Zakhama-Sraieb R, Charfi F. Spatio-temporal dynamics and biomass of Cymodocea nodosa in Bekalta (Tunisia, Southern Mediterranean Sea). Mar Ecol. 2017. https://doi.org/10.1111/maec.12383.

76. Terrados J, Medina-Pons FJ. Inter-annual variation of shoot density and biomass, nitrogen and phosphorus content of the leaves, and epiphyte load of the seagrass Posidonia oceanica (L.) Delile off Mallorca, western Mediterranean. Sci Mar. 2011;75(1):61-70.

77. Keulen M. Water flow in seagrass ecosystems. PhD thesis, Murdoch University, 1998.

78. Collier CJ, Lavery PS, Masini RJ, Ralph PJ. Morpjhological, growth and meadow characteristics of the seagrass Posidonia sinuosa along a depthrelated gradient of light availability. Mar Ecol Prog Ser. 2007;337:103-15.

79. Fraser MW, Kendrick GA. Belowground stressors and long-term seagrass declines in a historically degraded seagrass ecosystem after improved water quality. Sci Rep. 2017. https://doi.org/10.1038/s41598-017-14044-1.

80. Jones BL, Cullen-Unsworth LC, Unsworth RFK. Tracking nitrogen source using $\delta 15 \mathrm{~N}$ reveals human and agricultural drivers of seagrass degradation across the British Isles. Front Plant Sci. 2018;9:133. https://doi. org/10.3389/fpls.2018.00133.

81. Vieira VM, Engelen AH, Huanel OR, Guillemin M-L. Linear-in-the-parameters Oblique Least Squares: a case study with the estimation of densitydependent survival in algae with isomorphic biphasic life-cycles. PLoS ONE. 2016;11(12):e0167418. https://doi.org/10.1371/journal.pone.01674 18.

Ready to submit your research? Choose BMC and benefit from

- fast, convenient online submission

- thorough peer review by experienced researchers in your field

- rapid publication on acceptance

- support for research data, including large and complex data types

- gold Open Access which fosters wider collaboration and increased citations

- maximum visibility for your research: over 100M website views per year

At BMC, research is always in progress.

Learn more biomedcentral.com/submissions 